\title{
Residential Irrigation Water Costs in Osceola County and Orange County, Florida ${ }^{1}$
}

\author{
Nick Taylor, Tricia Kyzar, Pierce Jones, and Kaitlin O. Robb Price ${ }^{2}$
}

\section{Introduction}

Landscape irrigation is often the largest use of water for single-family homes that use automated, in-ground irrigation systems to maintain their landscapes. A home on a typical $1 / 4$-acre lot will use over two thousand gallons of water each time they irrigate. Water used for landscape irrigation can also make up a large portion of the overall water bill for single-family homes. Interest in understanding water use and irrigation costs has risen in recent years.

The following case study is an evaluation of water use and associated costs for residential landscape irrigation in Osceola County and Orange County, Florida. The information presented here can help stakeholders, such as utilities and local governments, understand key audiences and statistics for targeting conservation initiatives or policies. Homeowners in central Florida could also use the results to assess their water consumption and bills in relation to similar homes in the area.

\section{Methodology}

This case study is based on metered water consumption in Osceola County and Orange County, Florida, for calendar years 2012 through 2017 from three central Florida utilities: Toho Water Authority, Orange County Utilities, and the Orlando Utility Commission.

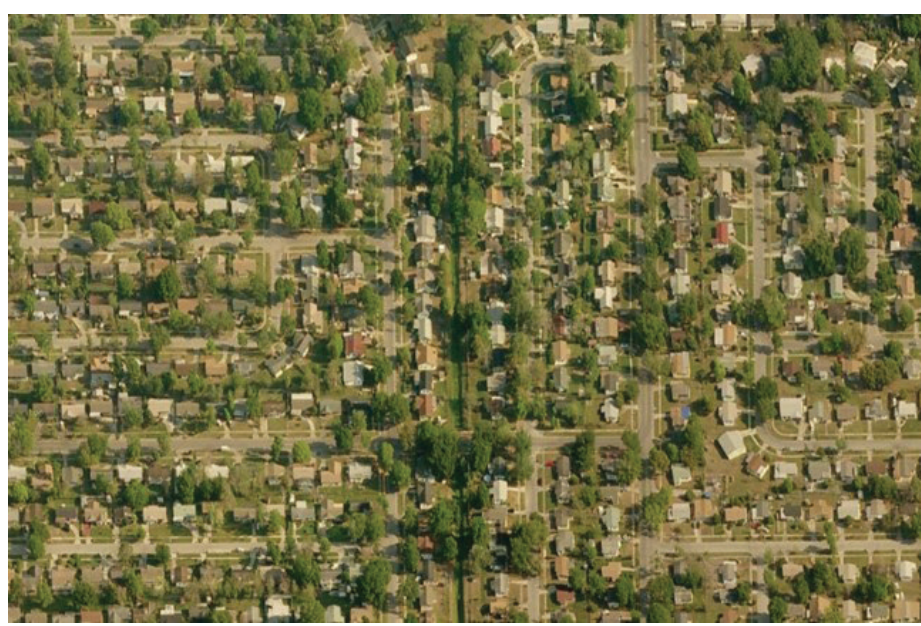

Figure 1. Single-family, detached homes. Credits: UF/IFAS

To ensure accurate estimates, consumption data were screened to remove outliers. This analysis includes singlefamily, detached homes with the following criteria:

- Serviced by Toho Water Authority, Orlando Utilities Commission, or Orange County Utilities

- Built (and occupied) between 2000 and 1 year prior to this analysis of consumption records

- (e.g., for 2016 consumption, homes built between 2000 and 2015)

- Part of a residential subdivision

- Fully occupied during the analysis year

1. This document is AE536, one of a series of the Department of Agricultural and Biological Engineering, UF/IFAS Extension. Original publication date December 2019. Visit the EDIS website at https://edis.ifas.ufl.edu for the currently supported version of this publication.

2. Nick Taylor, state specialized Extension agent; Tricia Kyzar, data analyst; Pierce Jones, professor and director; and Kaitlin O. Robb Price, communications specialist, Program for Resource Efficient Communities; UF/IFAS Extension, Gainesville, FL 32611.

The Institute of Food and Agricultural Sciences (IFAS) is an Equal Opportunity Institution authorized to provide research, educational information and other services

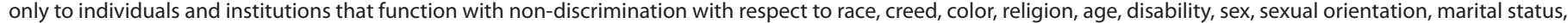

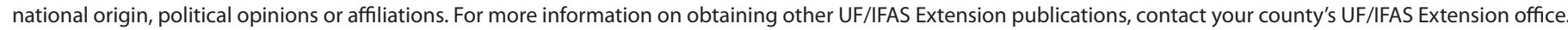
U.S. Department of Agriculture, UF/IFAS Extension Service, University of Florida, IFAS, Florida A \& M University Cooperative Extension Program, and Boards of County Commissioners Cooperating. Nick T. Place, dean for UF/IFAS Extension. 
- 12 months of non-zero indoor water use

- Regular irrigation system users

- Between $1 \mathrm{kgal}$ and $150 \mathrm{kgal}$ of outdoor use for at least 10 months

- On lots ranging from $1 / 8-1 / 4$ acre.

Appendix A shows a table of summary statistics for the study group, including the numbers of properties and averages of building characteristics.

After screening the data, billing rate structures obtained from each utility's website (retrieved on April 25, 2018) were applied to the monthly consumption values in each utility territory for the following subgroups:

- Dual-Potable-Dual-metered properties with both an indoor potable meter and an outdoor potable meter

- Dual-Reclaimed-Dual-metered properties with an indoor potable meter and an outdoor reclaimed water (treated wastewater) meter

- Single-Meter-Single-metered properties with indoor water and irrigation measured on the same potable water meter

Monthly consumption values for Single-Meter properties were disaggregated to evaluate irrigation use and costs. Single-meter properties, by nature, do not differentiate between potable water used for irrigation and potable water used for indoor use. Therefore, the average amount of water used indoors by dual-meter properties was used as an estimate of indoor use for single-meter homes. Since water use varies by month and year, the average indoor water use for dual-meter properties was calculated for each utility territory in each month of each year. Irrigation use was then calculated for each single-meter home in a given utility territory as the difference between their monthly total water use and the estimated indoor use for each month of each year. The same methodology was used to estimate the average cost of water used indoors by dual-metered properties (including the associated wastewater cost), and thus calculate irrigation cost for single-meter homes.

Average monthly water use and costs were calculated for the following groupings:

- All utilities together

- By utility

- By year

\section{Results}

\section{All Utilities Together}

The full study population included 58,072 properties, including 29,124 Single-Meter, 7,605 Dual-Potable, and 21,343 Dual-Reclaimed properties. Figures 2 and 3 provide a summary of water consumption and costs across all utility territories included in the study and across all years (2012-2017) for each subgroup. The overall average monthly irrigation use was $9.9 \mathrm{kgal} /$ month, at a cost of $\$ 29.20 /$ month. Properties in the Dual-Reclaimed subgroup had the highest monthly irrigation use (12.9 kgal/month) and properties in the Single-Meter subgroup had the lowest (6.7 kgal/month). Conversely, properties in the DualReclaimed subgroup had the lowest monthly irrigation cost (\$17.64/month) and properties in the Single-Meter subgroup had the highest (\$42.28/month).

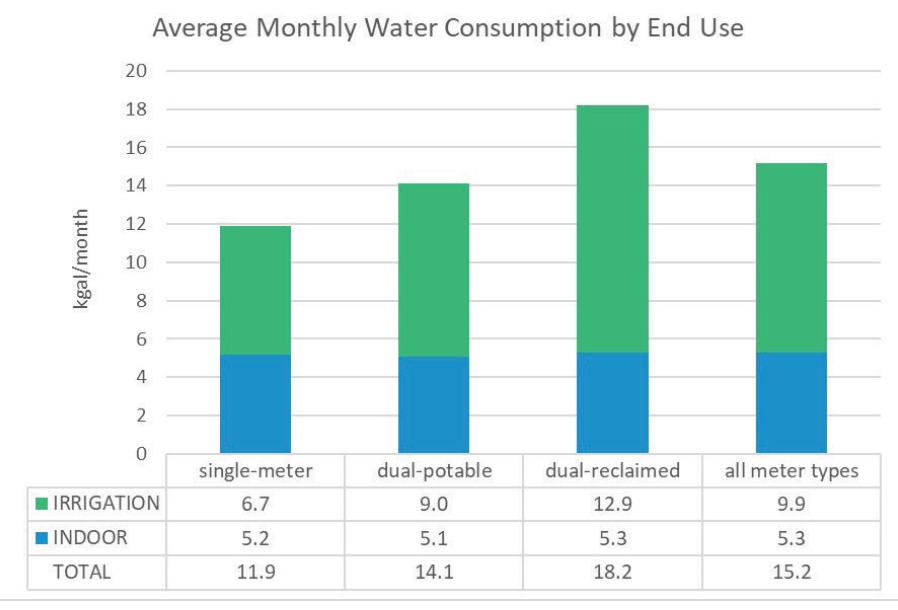

Figure 2. Average monthly water consumption by end use. Credits: UF/IFAS

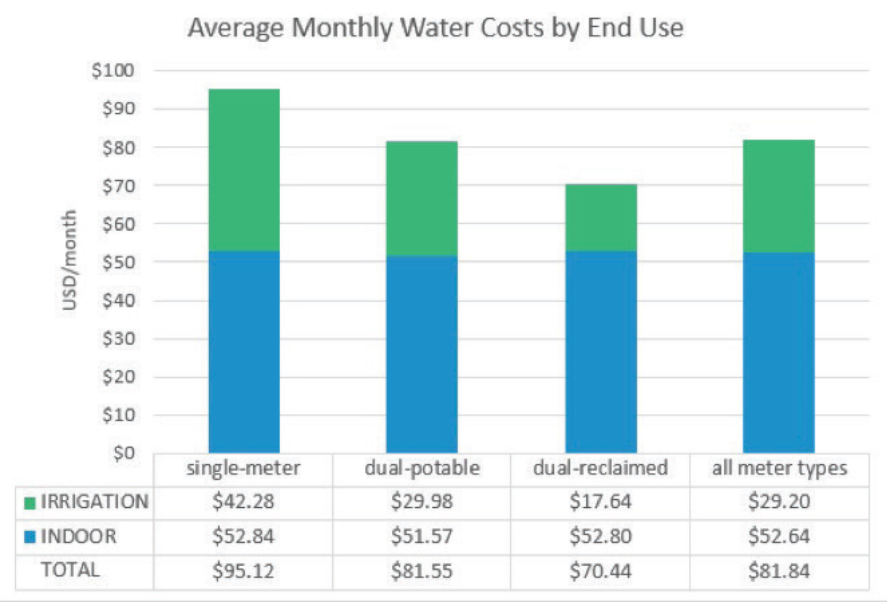

Figure 3. Average monthly water costs by end use. Credits: UF/IFAS

Table 1 (on page 5) gives the range and distribution of irrigation costs for each subgroup. Costs for Single-Meter properties are higher across all quartiles than Dual-Potable or Dual-Reclaimed properties. Median monthly irrigation 
costs range from $\$ 12.74$ for Dual-Reclaimed properties to $\$ 31.30$ for Single-Meter properties, with Dual-Potable properties at $\$ 21.43$. For the highest Single-Meter users in the $99^{\text {th }}$ percentile, irrigation costs are nearly $\$ 200$ per month.

\section{BY UTILITY}

Figures 4 and 5 show average consumption and cost, respectively, for each utility over the five-year study period (2012-17). The "ALL" column is the average cost across all utilities for all years of the study by subgroup.

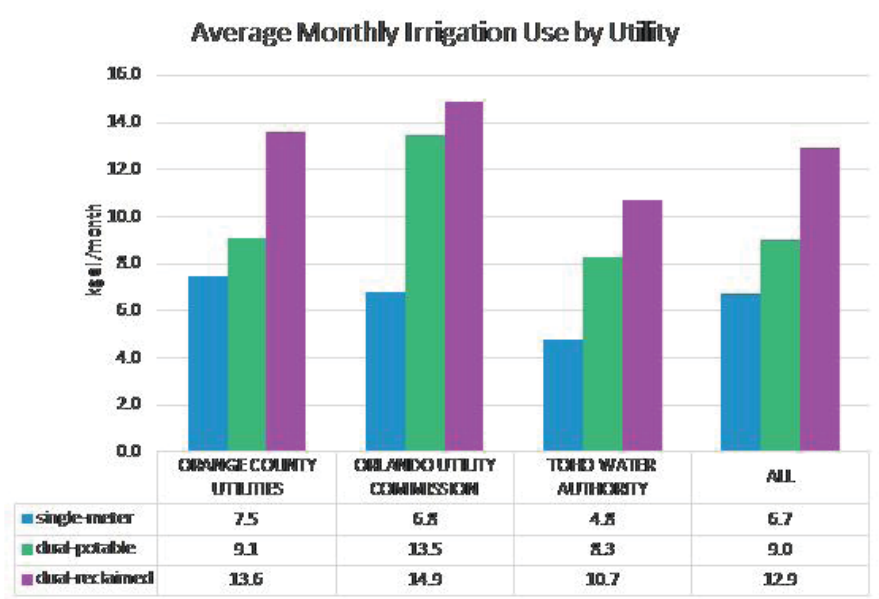

Figure 4. Average monthly irrigation consumption for each utility territory and across the analysis region.

Credits: UF/IFAS

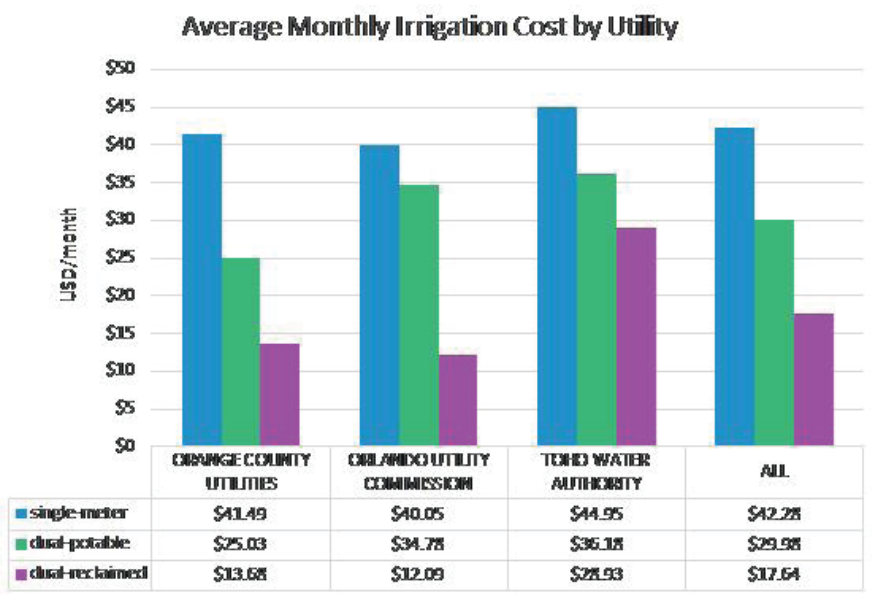

Figure 5. Average monthly irrigation costs for each utility territory and across the analysis region.

Credits: UF/IFAS

\section{BY YEAR}

Figures 6 and 7 show average consumption and cost, respectively, for each year across all utility territories included in the study. Data labeled "all meter types" give monthly averages across all properties included in the study each year.

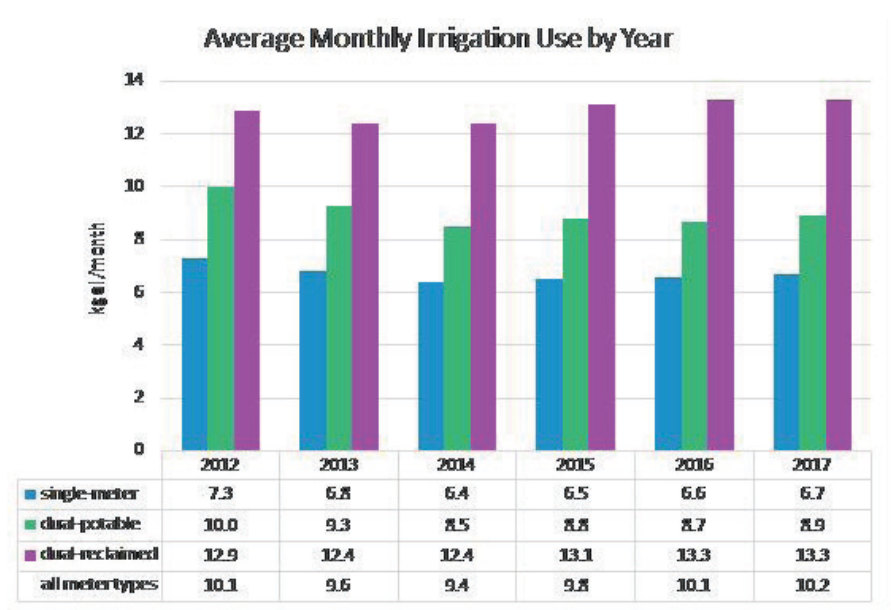

Figure 6. Average monthly irrigation consumption for each utility territory and across the analysis region.

Credits: UF/IFAS

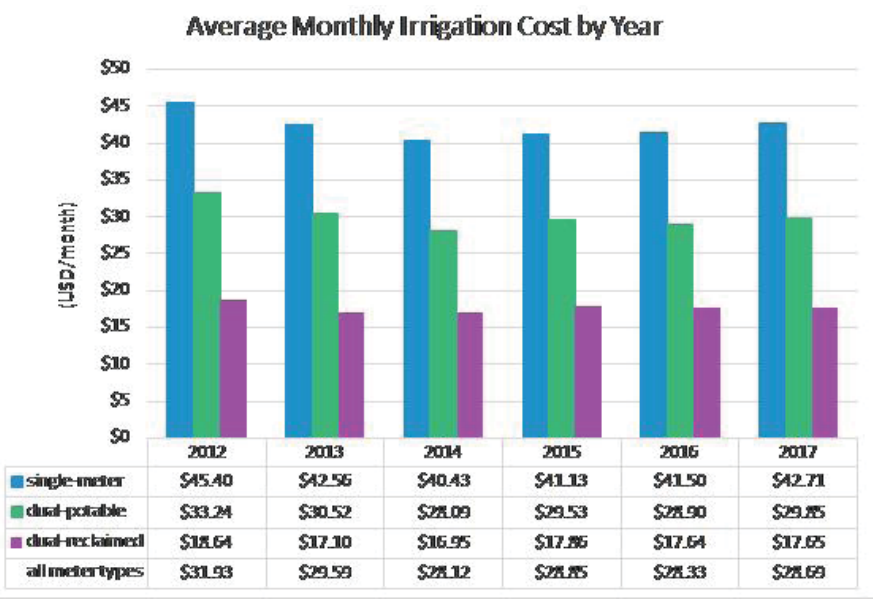

Figure 7. Average monthly irrigation costs for each utility territory and across the analysis region.

Credits: UF/IFAS

\section{Summary}

In Osceola County and Orange County, homes with reclaimed water are using disproportionately more water on irrigation, and this reclaimed water is charged at a lower rate. As a result, of the three metering scenarios analyzed, homes with dual-reclaimed meters use the most water but have the lowest utility bills. Although single-meter homes use the least water, their utilities bills were the highest, on average, of the three meter types. The inverse relationship between water use and associated cost was consistent for the three utility territories, together, during the five-year period, as well as for each individual utility and year.

Therefore, financial savings may be a significant motivator for homes with single or dual-potable meters to reduce their water consumption. Conversely, financial savings may be less of a motivator for those with dual-reclaimed meters. Reducing outdoor water use is critical "... because it results in environmental benefits and allows for more water in the aquifers, streams, springs, and lakes for environmental, 
agricultural, or other important uses" (Borisova et al. 2017). In addition, reclaimed water contains nutrients that are not removed during the wastewater treatment process. If reclaimed water is overused, it can lead to runoff or leaching that may harm our surface water and/or our aquifer (Toor and Lusk 2011). Understanding the relationship between water use and associated costs can help inform conservation strategies in central Florida.

\section{References}

Borisova, T., L. A. Warner, J. Searcy, A. K. Chaudhary, and M. Dukes. 2017. Estimating Benefits of Residential Outdoor Water Conservation: A Step-by-Step Guide. FE1009. Gainesville: University of Florida Institute of Food and Agricultural Sciences. http://edis.ifas.ufl.edu/fe1009

City of Orlando. 2018. "Understand Your Sewer Billing Rates." Accessed on December 3, 2019. http://www.cityoforlando.net/waterreclamation/billing-rates/

Orange County Utilities. 2018. "Water, Wastewater \& Reclaimed Water Rates." Accessed on December 3, 2019. https://www.orangecountyfl.net/Portals/0/Library/ Water-Garbage-Recycle/docs/WaterWastewaterReclaimedWaterRates.pdf

OUC. 2018. "Water Rate Schedule." Accessed on December 3, 2019. https://www.ouc.com/docs/rates/rates_water_2018. pdf?sfvrsn $=4$

Toho Water Authority. 2018. "Toho Water Authority Rates Schedule." Accessed on December 3, 2019. https://www. tohowater.com/customerservice/Documents/Toho\%20 Water\%20Authority\%20Rates.pdf

Toor, G. S., and M. Lusk. 2018. Reclaimed Water Use in the Landscape: Frequently Asked Questions about Reclaimed Water. SL339. Gainesville: University of Florida Institute of Food and Agricultural Sciences. https://edis.ifas.ufl.edu/ ss544 
Table 1. Distribution of monthly irrigation consumption and cost for each subgroup.

\begin{tabular}{|c|c|c|c|c|c|}
\hline \multicolumn{6}{|c|}{ DISTRIBUTION OF MONTHLY IRRIGATION CONSUMPTION AND COST } \\
\hline & 1st Pctl & 25th Pctl & Median & 75th Pctl & 99th Pctl \\
\hline \multicolumn{6}{|c|}{ CONSUMPTION (KGAL) } \\
\hline SINGLE-METER & 1.3 & 2.8 & 4.9 & 8.7 & 27.7 \\
\hline DUAL-POTABLE & 1.1 & 4.4 & 7.5 & 11.9 & 31.9 \\
\hline DUAL-RECLAIMED & 1.2 & 6.0 & 10.3 & 16.4 & 54.3 \\
\hline \multicolumn{6}{|c|}{ COST (USD) } \\
\hline SINGLE-METER & $\$ 7.06$ & $\$ 17.49$ & $\$ 31.30$ & $\$ 56.14$ & $\$ 194.41$ \\
\hline DUAL-POTABLE & $\$ 8.53$ & $\$ 14.54$ & $\$ 21.43$ & $\$ 34.98$ & $\$ 141.79$ \\
\hline DUAL-RECLAIMED & $\$ 2.67$ & $\$ 7.21$ & $\$ 12.74$ & $\$ 21.21$ & $\$ 91.65$ \\
\hline
\end{tabular}

\section{APPENDIX A-Summary Statistics for Study Properties}

In order to provide greater context for the results, the summary statistics below include the number of properties and the typical characteristics of the homes analyzed in this study.

\section{Appendix Definitions}

- Properties-The number of dual-metered, single-family, detached properties

- Dual Potable-The number of dual-metered, singlefamily, detached properties with a potable outdoor meter as the second meter

- Dual Reclaimed-The number of dual-metered, singlefamily, detached properties with a reclaimed outdoor meter as the second meter

- Year Built-Average year when construction was completed for properties

- Beds-Average number of bedrooms

- Baths-Average number of bathrooms
- Living SqFt-Average conditioned floor area of properties included in the study

- Parcel SqFt-The average square feet of the parcel of properties included in the study

- Have Pool-Number of properties with pools

- If a pool represents a substantial increase in water use, then the cost of irrigation for a single-metered property could be higher due to the inclining block rate cost structure.

- Owner-Occupied-Number of properties with homestead exemptions indicated in appraisal records

- Properties with homestead exemptions are considered to be the primary, permanent, year-round residence of the owner.

\begin{tabular}{|c|c|c|c|c|c|}
\hline & & $\begin{array}{l}\text { ORANGE COUNTY } \\
\text { UTILITIES }\end{array}$ & $\begin{array}{l}\text { ORLANDO UTILITY } \\
\text { COMMISSION }\end{array}$ & $\begin{array}{l}\text { TOHO WATER } \\
\text { AUTHORITY }\end{array}$ & ALL \\
\hline \multirow[t]{4}{*}{ NUMBER OF } & PROPERTIES & 28,543 & 6,683 & 22,846 & 58,072 \\
\hline & SINGLE METER & 11,806 & 3,913 & 13,405 & 29,124 \\
\hline & DUAL POTABLE & 4,105 & 383 & 3,117 & 7,605 \\
\hline & DUAL RECLAIMED & 12,632 & 2,387 & 6,324 & 21,343 \\
\hline \multirow[t]{6}{*}{ AVERAGES } & YEAR BUILT & 2006 & 2008 & 2006 & 2006 \\
\hline & BEDS & 3.9 & 3.8 & 3.7 & 3.8 \\
\hline & BATHS & 2.7 & 2.7 & 2.5 & 2.6 \\
\hline & LIVING SQFT & 2,501 & 2,525 & 2,179 & 2,377 \\
\hline & PARCEL SQFT & 7,584 & 7,383 & 7,796 & 7,644 \\
\hline & IRRIGABLE SQFT & 7,530 & 7,261 & 6,879 & 7,243 \\
\hline \multirow[t]{2}{*}{ PERCENTAGES } & HAVE POOL & $21 \%$ & $18 \%$ & $23 \%$ & $21 \%$ \\
\hline & OWNER-OCCUPIED & $68 \%$ & $68 \%$ & $52 \%$ & $62 \%$ \\
\hline
\end{tabular}

